Volume 7 Issue 1, March 2020

Nationally Accredited Journal,

Decree No. B/4130/E5/E5.2.1/2019

\title{
Legal Protection for Debtors over Separatist Creditors' Rights Related To Bankruptcy
}

\begin{abstract}
Sutrisno ${ }^{1}$
Abstract. Indonesia, as a rechtstaat country, has consequences for the protection and respect of human rights of every class of society; for this reason the law in Indonesia must be able to realize the mandate of Article 28D paragraph (1) of the 1945 Constitution of the Republic of Indonesia. This includes legal protection for debtors over the rights of separatist creditor billing when bankruptcy occurs. In fact, the implementation of legal protection for debtors has not been able to do fairly up to now; this can occur because 1) the requirements for requesting bankrupt statements make it easy for debtors to go bankrupt, even though the debtor is actually in a state of solvency; 2) the PKPU mechanism has not provided extensive opportunities for debtors to improve company performance; and 3) efforts in bankruptcy are dominated by the authority of creditors. While, the problems that have resulted in the implementation of legal protection for debtors over the separatist creditor's collection rights so far are as follow: 1) there has been no funds for the costs of arranging and clearing bankrupt assets; 2) the bankrupt debtor is not cooperative and 3) the debtor sells / transfers his assets before being declared bankrupt. The method used in this paper is sociological juridical with non-doctrinal approach.

Keywords: Debtor; Separatist Creditor Rights; Bankruptcy; Legal Protection.
\end{abstract}

\section{Introduction}

Indonesia is a state of law that is clearly stated in Article 1 paragraph (3) of the 1945 Constitution of the Republic of Indonesia. This clearly also mandates the existence of legal protection for all people without discrimination to certain community. This mandate is also clearly stated in Article 28D paragraph (1) of the 1945 Constitution of the Republic of Indonesia.

Broadly speaking, guarantees are stipulated in the laws and regulations of the Republic of Indonesia has the following principles: ${ }^{2}$

- The guarantee right gives priority to the creditors holding the right of guarantee to the other creditors;

- The guarantee right is the right of assessoir for the principal agreement guaranteed by the agreement. The guaranteed principal agreement is an agreement of debts between the creditor and the debtor, meaning that if the principal agreement ends, the guarantee agreement for the law ends as well;

- The guarantee rights provide separatist rights for creditors of the guarantee rights holding. This means that the objects burdened with collateral rights do not constitute bankrupt assets in the event that the debtor is declared bankrupt by the court;

- The Guarantee rights are property rights over real rights, which means that the guarantee rights will always be attached to the object or always follow the object to anyone who owns the property or droit de suite;

- Creditor holders of guarantee rights have full authority to execute their guarantee rights. This means that the creditor of the guarantee right holding has the authority

\footnotetext{
${ }^{1}$ Lecturers Of Faculty Of Law, UNISSULA, Semarang, email drsutrisnosag@gmail.com

2 Ibid Hal. 32-33
} 
to sell by himself, both based on a court ruling or based on the powers granted by law, objects that are burdened with the guarantee right, and take the proceeds from the sale to repay the debts to the debtor;

- Because it is a material right, the guarantee rights apply to third parties, the guarantee rights apply to the principle of publicity. This means that the guarantee rights must be registered at the relevant guarantee rights registration office.

From the above explanation it can be clearly said that the creditor's rights and obligations are as collateral or lending institutions to provide financial assistance to the debtor, where it is registered with the relevant insurance guarantor, and in this case the creditor is entitled to receive guarantees from a debtor; and if this does not occur repayment of the debt by the debtor, the creditor has the right to execute the collateral by selling or declaring the debtor to be bankrupt because he is unable to pay the debt.

The understanding of the debtor, namely someone who has a debt. In the case of the rights and obligations of a debtor is the opposite of the rights and obligations of creditors. Because a debtor is a person who has a debt, then the obligation is to pay off the debt to the creditor. In addition, the debtor also has an obligation in the form of providing collateral to the creditor as collateral for his debt, as soon as the debtor pays off, the debtor has the right to accept the items back as collateral for loans to the creditor.

In this case a person said to be a debtor is a person or individual, in this case both men and women can be declared bankrupt by the court if (s)he is unable to pay debt to one or more creditors. Associations or associations that are not legal entities such as maatschap, firms and limited associations, corporations or associations with legal entities such as limited liability companies (PT), cooperatives and foundations.

In order to protect the rights and obligations of each party (debtors and creditors) the Bankruptcy and PKPU Law was issued. The Bankruptcy and PKPU Law is the amendment Act from Law Number 4 of 1998 concerning the Establishment of Government Regulations in lieu of Law Number 1 of 1998 concerning Amendment to the Law on Bankruptcy into Law.

The Bankruptcy Law and PKPU accommodate the problem solving model that arises due to the agreement on receivables with bankruptcy and / or postponement of the obligation to pay receivables. Bankruptcy is carried out by conducting public confiscation of all the assets of the bankrupt Debtor, which is administered and carried out by the Curator under the supervision of the Supervising Judge as regulated in the Act. A debtor can be declared bankrupt if the debtor has two or more creditors and does not pay off at least one receivable that has fallen due and can be billed (Article 2 paragraph (1) of the Bankruptcy Law and PKPU). While the postponement of the obligation to pay receivables (PKPU) is concentrated to provide an opportunity for debtors who, at maturity, have not been able to pay the receivables but may be able to pay the receivables at a later date. In other words, PKPU is an alternative way given to debtors to ease the burden of paying accounts receivable to creditors by extending for a certain period. Of course the determination of the limit on the term of payment of the receivables is based on the agreement of both parties, namely creditors and debtors. This model is also known as the debt restructuring concept ${ }^{3}$.

\footnotetext{
${ }^{3}$ Debt restructuring according to Joel G. Sigel and Koe K.Shin is an adjustment or restructuring of the structure of receivables that reflects the opportunity for the debtor to plan the fulfillment of its debt obligations. Scheduling is required when the debtor faces financial difficulties. Agreements to change the structure can be caused by legal action or based on simple agreement from the parties concerned. The debt restructuring structure is based on voluntary
} 
The debt restructuring concept above is regulated in Article 222 of the Bankruptcy and Deferment of Debt Payment Obligations (PKPU) Law which reads:

Article 222

(1) Deferment of the obligation to pay the Receivables is submitted by a Debtor who has more than 1 (one) creditor or by the creditor;

(2) Debtors who are unable or foreseeable will not be able to continue to pay their debts which are past due and collectible, may request a postponement of the obligation to pay the receivables, with a view to submitting a peace plan that includes offering to pay part or all of the receivables to the creditor;

(3) Creditors who estimate that the debtor cannot continue to pay their receivables that are past due and collectible, may request that the debtor be given a postponement of the obligation to pay the receivables, to enable the debtor to submit a peace plan which includes offering payment of part or all of the receivables to his creditors.

Based on the contents of Article 222 of the Bankruptcy and PKPU Law, both creditors and debtors can submit applications for postponement of debt payment obligations. However, in fact the existence of creditors who can submit requests for postponement of the obligation to pay receivables actually causes problems. This was stated by Ricardo Simanjuntak as Chair of the Advisory Board of the Indonesian Curator and Management Association (AKPI) that Article 222 paragraph (3) of the Bankruptcy and PKPU Law had weaknesses because it provided an opportunity for creditors to be able to submit PKPU to debtors. In fact, PKPU must be submitted by the debtor or the company in debt because the debtor is the party who knows and recognizes the company's financial condition. ${ }^{4}$

In addition, Article 2 paragraph (1) of the Bankruptcy and PKPU Law does not provide uniform interpretation in its implementation. Article 2 paragraph (1) of the Bankruptcy and PKPU Law states that the debtor has two or more creditors and does not pay off at least one person who is due and can be billed, declared bankrupt by a court decision either at his own request or at the request of one or more of his creditors. Based on the description of the article, more or less parties who can file for bankruptcy applications, among others: ${ }^{5}$

- The debtor himself, on condition that the debtor has at least two creditors and does not pay off at least one receivable that is due and can be billed;

- Creditors who have receivables from debtors who are past due and can be billed;

- Prosecutor's Office or public prosecutor;

- Central Bank of Indonesia (Bank Indonesia) if it concerns debtors who are banks;

- Capital Market Supervisory Agency, if it concerns debtors who are securities companies, namely parties conducting activities as Underwriters, Securities Trading

financial management decisions, for example to change the scale of short-term receivables to long-term receivables. Tjiptono Darmadji, Restrukturisasi: Memulihkan dan Mengakselerasi Ekonomi Nasional,( Jakarta: Grasindo, 2001), pp.69.

4 Accessed through http://industri.bisnis.com/read/20170408/12/643747/minta-revisi-uukailitan-simak-alasannya on September 25, 2018 at 11:00 a.m.

${ }^{5}$ Khardiyanti Habri, et al, Settlement of Article 2 paragraph (5) of Law Number 37 of 2004 about Bankruptcy and Suspension of Obligations for Payment of Receivables (PKPU) and Article 55 paragraph (1) of Law Number 19 of 2003 about State Owned Enterprises related to Authority to bankrupt a public company, Journal of the Notary Masters Study Program Faculty of Law, Brawijaya University, Malang, pp.4-5. 
Intermediaries, and / or investment managers as regulated in Law Number 8 of 1995 about Capital Markets;

- The Minister of Finance, if it concerns debtors who are Insurance Companies, Reinsurance Companies, Pension Funds, or State-Owned Enterprises engaged in the field of public interest.

The many subjects of bankruptcy and PKPU applicants on the one hand provide easy access but on the other hand the arrangements are not yet harmonious with each other for example relating to Law Number 45 of 2007 about Investment and Law Number 40 of 2007 about Limited Liability Companies.

Basically, the problem that is often problematic is that the PKPU implementation period is too short. Article 225 paragraph (4) of the Bankruptcy and PKPU Law states that:

Immediately after the decision to postpone the obligation to pay the temporary debt, the Court through the management must summon debtors and creditors known as registered letters or by courier, to appear in a hearing that is held no later than 45 (forty-five) days from the decision to postpone the payment of temporary receivables be spoken.

The basic idea of PKPU is to provide an opportunity for debtors to reorganize or reorganize their business. Realignment of a business certainly requires quite a long time. The time given by Article 225 paragraph (4) of the Bankruptcy and PKPU Law above is considered insufficient to provide an opportunity for the debtor to restructure his business. Considering that for 45 days the debtor must complete a peace proposal, lobby and reorganize the business. In short the time seemed to provide benefits to creditors. ${ }^{6}$

PKPU's petition is basically only a way for debtors to avoid bankruptcy requests submitted by creditors. The large number of subjects who can submit PKPU requests to the Commercial Court has led to the blurring of legal protection limits for creditors. Considering the efforts of PKPU according to Article 229 paragraph (3) of the Bankruptcy and PKPU Law states that in the case of a PKPU and bankruptcy application filed together at the Commercial Court, the application for PKPU will be examined and decided upon in advance. ${ }^{7}$ Therefore, the main basis for PKPU's request is a good intention delivered by the debtor or creditor.

Furthermore, the Bankruptcy Law and PKPU are seen as participating in regulating premature liquidation. This has an impact on the degradation of domestic and foreign investor confidence which tends to hamper the pace of domestic investment. So far, the Supreme Court through the Decision of Cassation has often cancelled the Decision on the bankruptcy statement on the basis of Article 2 of the Bankruptcy and PKPU Law because parties who can file bankruptcy applications for State-Owned Enterprises (BUMN) are out of sync with the BUMN Law. In addition, Article 2 paragraph (3) to paragraph (5) of the Bankruptcy and PKPU Law also regulates the authority to submit bankruptcy applications by the prosecutor, Bank Indonesia, the Financial Services Authority (OJK), and the Ministry of Finance who are not creditors. ${ }^{8}$

Another problem that arises is the subject of curatorial authority. At the level of practice, curatorial authority tends to exceed the limits because it acts as an advocate and as a result the curator is difficult to touch by law. The lack of supervisory functions

\footnotetext{
${ }^{6}$ Accessed via m.hukumonline.com/berita/baca/lt56173ed1a1cb/enam-fever-uu- bankruptcy on September 27, 2018 at 11:00 a.m.

${ }^{7}$ Article 223 paragraph (3) of Law Number 37 Year 2004 about Bankruptcy and Suspension of Payment Obligations.

${ }^{8}$ Accessed via https://bhpsemarang.com/berita- bankruptcy-and-pkpu.html on September 27, 2018 at 10:00 a.m.
} 
in carrying out the duties of the curator to oversee the integrity of the curator, the authority of the responsibility and compensation for the services of the curator, the bankruptcy conditions which are considered too easy and the lack of protection for the debtor. In this case the debtor becomes the injured party. In addition to adding standards and supervision to its economical curators, coordination between professional organizations that oversees the curators, namely the Indonesian Curator and Management Association (AKPI), the Indonesian Curator and Management Bond (IKAPI), and the Indonesian Curator and Management Community (HKPI). The difference in mind set and interpretation of each of the curator's organizational performance above tends to influence the curator's professionalism in serving debtors and creditors. ${ }^{9}$

Another major problem today, can be seen in Article 2 (paragraph 1) of Law Number 37 of 2004 about irrational bankruptcy requirements because a request for bankruptcy can be filed and a decision on bankruptcy by the Commercial Court can be imposed on debtors who are still solvent, (i.e. a debtor whose assets are greater than the total amount of the receivables). With such bankruptcy conditions, legal certainty and the objective of implementing a bankruptcy law that is fair will be very difficult to achieve. In addition, Law Number 37 of 2004 pays more attention to and protects the interests of the bankrupt creditor than the interests of the bankrupt debtor which should also be protected. This means that Law Number 37 of 2004 should pay attention and provide balanced legal protection both to the interests of creditors and debtors in accordance with the principle of bankruptcy in general, namely the principle of providing benefits and balanced legal protection between creditors and debtors and the principle of encouraging investment and business. ${ }^{10}$

The conditions for bankruptcy as referred to in Article 1 "Faillissements-Verordening", which came into force on November 1, 1906, even though it only gives the possibility to submit a bankruptcy request to a debtor in an inability (Van de voorziening in geval van onvermogen van kooplieden ) or cannot afford to be real (kennelijk onvermogen) so it is in a state of stopping paying back its debts. This means that the debtor is insolvent (more liabilities than assets and accounts receivable), whereas debtors who are still solvents (smaller obligations than assets and receivables) should the Curator ask the debtor to jointly find a solution to pay off their obligations by improving management, one example is the curator and the debtor conduct an independent audit to find out the debtor's problem so that the curator does not directly procure assets from the bankrupt debtor. ${ }^{11}$

In its development, the position of the debtor bankrupt by the separatist rights of creditors results in injustice, especially in terms of the legal protection of the debtor. So it is interesting if a deeper study is conducted regarding "Legal Protection of Debtors on the Rights of Separatist Creditor Related to Bankruptcy".

The issues that will be discussed in this article are related to the implementation of legal protection of debtors on the rights of separatist creditors at this time and the problems that exist in the implementation of legal protection against debtors on the rights of separatist creditors at this time.

9 Accessed via http://google.com/amp/amp.kontan.co.id/news/ruu-pailit-perketat- mov-parakurator accessed on 27 September 2018 at 10.15 a.m.

${ }^{10}$ Accessed via https://www.hukumonline.com/pusatdata/detail/320/node/19/undangundangnomor-4-tahun-1998/, on 4 July 2019.

${ }^{11}$ Loc.cit 
eISSN : 2581-2114, pISSN: 2406-9426

\section{The Method Used}

The method used in writing this article is sociological juridical, while the approach used is the non-doctrinal approach.

\section{Resultsd and Discussion}

\subsection{Execution of Legal Protection Against Debtors of Separatist Creditor Rights Right Now}

Debt is a major problem in the bankruptcy proceedings, because without a debt it is not possible for bankruptcy matters to be examined. Without the debt, then the essence of bankruptcy becomes non-existent because bankruptcy is a legal institution to liquidate debtor assets to repay debts to its creditors. ${ }^{12}$

Likewise with the concept of debt in the Dutch bankruptcy law which is also enforced in Indonesia with the principle of concordance in bankruptcy regulations, that debt is a form of obligation to fulfil achievements in an engagement. Fred B.G Tambunan said that in the case of someone due to their actions or not doing something resulted that he had the obligation to pay compensation, give something or not give something, then at that time also had a debt, had an obligation to do achievement. ${ }^{13}$ So debt equals achievement. Jerry Hoff also believes that debt refers to obligations in civil law. Obligations or debts can arise either from the agreement or from the law. ${ }^{14}$

So determine who is entitled to the bill against the assets of the bankrupt Debtor, including major problems in bankruptcy because in the process of bankruptcy the most essential thing is actually the distribution of the assets of the bankrupt Debtor to its Creditors, separatist creditors or special group creditors. Separatist creditors or special group creditors are creditors who can execute their rights as if bankruptcy did not occur (Article 55 UUK). This special class of creditors can sell their own goods that are guaranteed as debt as if there is no bankruptcy. From the proceeds of the sale, the creditor takes as much as his debt as payment, while the rest is deposited to the curator. If it turns out the sales results are less than the amount of the receivables, then he can join as a concurrent creditor for the rest. ${ }^{15}$

Separatist creditors have certain ties and their rights are guaranteed by certain agreements, therefore their position is beyond bankruptcy. This means they are not verified but are included in the distribution list and registered with the Curator. Being included in preferred creditors and concurrent creditors must be verified in the verification meeting and included in the distribution list.

A separatist creditor who relinquishes his right to execute collateral himself as if there is no bankruptcy or whose right to execute has expired, that is 2 (two) months after insolvency, is paid by the Curator from the proceeds of the sale of the bankrupt goods which become collateral for a number of Mortgage value / Pawn / fiduciary. If the proceeds from the sale turn out to be less than the value of the Mortgage / Pawn / Fiduciary Rights, then the shortfall will be a concurrent bill, and if it turns out that the

\footnotetext{
${ }^{12}$ Hadi Shubhan, Op.cit., p. 34.

${ }^{13}$ Fred BG Tumbuan, 2005, "Observing the Meanings of Debtors, Creditors and Debt Relating to Bankruptcy" in: Emmy Yuhassarie, Bankruptcy Law and its development, Center for Legal Review, Jakarta, p. 7. Also see, Hadi Shubhan, op.cit., P. 35

${ }^{14}$ Ibid.

${ }^{15}$ Agus Sudradjat, Bankruptcy and Its Relationship with Banking Institutions, Paper on National Seminar of Bankruptcy Institutions in Reforming Economic Law in Indonesia, Faculty of Law, Soegijapranata Catholic University, Semarang, 1996, p. 4
} 
sales proceeds in excess, then the excess is entered into bankrupt assets. Likewise, if a separatist creditor exercises his own execution rights, he is only entitled to take the amount of the Mortgage / Pawn / Fiduciary Rights and the excess must be left to the Curator to become bankrupt property, on the contrary if the deficiency becomes a concurrent bill as long as the registration opportunity for the Creditor Bill he also registers the bill.

\subsection{Issues in the Implementation of Legal Protection of Debtors of the Current Separatist Creditor Rights}

The problems that affect the implementation of the legal protection of the debtor on bankruptcy committed by the separatist creditor are: ${ }^{16}$

\subsubsection{There is no funding yet for the costs of arranging and clearing bankrupt assets.} Settlement of a bankruptcy requires funds that are not small, so the Curator receives a decision of the bankruptcy statement from the Commercial Court in a relatively short time must prepare funds for the announcement of a summary of the decision of the bankruptcy statement and the deadline for filing Creditors / organizing a meeting of credit matching. The announcement as regulated in Article 15 paragraph (4) and Article 114 requires funds of more than IDR 10,000,000 (ten million rupiah) and there is no post in the routine budget of the Legacy Treasury.

The Corruption Law (UUK) has actually anticipated the possibility of difficulties / obstacles for the Curator in financing to carry out the tasks of managing and acquiring bankrupt assets in the presence of Article 107 paragraph (1) above. Implementation in the field of selling bankrupt assets requires time because they are demanded to sell at maximum prices so as not to harm bankrupt assets, in addition there must be a Supervisory Judge permission which means that to obtain these permits also requires time while the funds must be fulfilled immediately.

\subsubsection{Bankrupt debtors are not cooperative}

The curator needs data about the assets of the Debtor to make a record of bankrupt assets as regulated in Article 100 paragraph (1) of the UUK stating: "The curator must make a record of bankrupt assets no later than 2 (two) days after receiving the decision to appoint him as Curator."

Bankrupt debtors who do not cooperate in providing data on their assets will make it difficult for the Curator to record bankrupt assets. Bankrupt debtors who are not present at the accounts receivable matching meeting that have been set up will result in the delay of the credit matching meeting. Based on Article 121 paragraph (1) the presence of a bankrupt Debtor is mandatory, so that if a bankrupt Debtor is not present at the credit matching meeting, the meeting cannot proceed and the Supervisory Judge will postpone it. Delayed accounts receivable matching meetings will increase the length of bankruptcy settlement.

\subsubsection{Bankrupt debtors sell / hide their assets before being declared bankrupt.}

The task of the Curator is to manage and / or procure bankrupt assets, so that if there are assets of a Bankrupt Debtor that have been sold before bankruptcy, the Curator

\footnotetext{
${ }^{16}$ Maria Regina Fika Rahmadewi, Settlement of Debtor Debt to Creditors Through Bankruptcy, Thesis, Magister of Notary Undip, 2007, p. 89-91.
} 
must take care of when the sale and to whom the asset is sold. Tracking Debtor assets that have been sold / hidden and the cancellation process requires a long time and a lot of costs; this is clearly an obstacle in the settlement of Debtor debt to Creditors through bankruptcy.

Efforts that can be made to overcome the factors in implementing debtor's legal protection against bankruptcy are as follows: ${ }^{17}$

- There is no funding yet for the costs of arranging and clearing bankrupt assets.

The way the Legacy as a Bankruptcy Curator to overcome the lack of funds to finance the management and settlement of bankrupt assets is to make loans to third parties. This method is a step that can be accounted for. Article 69 paragraph (2) b states "in carrying out their duties, the Curator may make loans from third parties, only in the context of increasing the value of bankrupt assets".

The Curator carries out the task of arranging and / or acquiring bankrupt assets for the benefit of the Debtor and the Creditors, so that if the Curator experiences funds difficulties then takes steps to borrow from a third party to be used to take care of the interests of the Debtor / Creditors, of course these steps can be justified. The Curator Loan will certainly be returned after the bankruptcy assets have been sold.

- Bankrupt debtors are not cooperative

How to deal with Bankrupt Debtors who are not cooperative in the case of data requested about their assets by the Curator, as described in advance include coordinating directly or by letter with the bank to obtain data about Debtor deposits in a bank. Banks usually object to giving data about the amount of their customers' deposits on the grounds of bank secrecy, to penetrate bank secrecy the curator must provide a strong legal basis, namely the explanation of Article 105 of the UUK which reads as follows:

Based on Article 24 and Article 69, since the decision of the bankruptcy all utilities of the Debtor to control and manage bankrupt assets including obtaining information about the books, records, bank accounts, and deposits of the Debtor from the bank concerned is transferred to the Curator.

Non-cooperative bankruptcy means hindering the bankruptcy settlement process, so that the Curator can take decisive action to deal with an uncooperative Debtor by using the legal basis of Article 93 paragraph (1), namely asking the Commercial Court to arrest the Bankrupt Debtor.

- Bankrupt debtors sell / hide their assets before being declared bankrupt.

The way to overcome obstacles to Bankrupt Debtors who sell / hide their assets before being declared bankrupt, as described in the results of the Curator's action research, is to file a lawsuit to cancel the sale, while the assets that are being hidden are reported to the Police.

The legal actions of a Bankrupt Debtor selling its assets 1 (one) year before it is declared bankrupt can be cancelled based on Article 41 paragraph (1) of the Law on Manpower. The act of the Probate Court overcomes obstacles to the actions of the Bankrupt Debtor who has sold its assets by making a lawsuit is a professional action, as the Curator must make maximum efforts to return the assets that have been sold into bankrupt assets while the buyer will usually maintain so that what he buys is not released.

Debtor assets / assets that are hidden before a bankruptcy statement are bankrupt assets. Bankrupt debtors who hide their assets before being declared bankrupt

17 Maria Regina Fika Rahmadewi, Settlement of Debtor Debt to Creditors Through Bankruptcy, Thesis, Magister of Notary Undip, 2007, p. 92-94. 
means embezzlement of bankrupt assets. The way the Probate Court overcome the obstacles to settling debtors' debts against creditors through bankruptcy, because the Bankruptcy Debtor hides his assets before being declared bankrupt, by taking peace before taking firm action to report to the Police is a wise enough action.

\section{Clossing}

\subsection{Conclusion}

- The implementation of the Bankruptcy Law has not provided protection to debtors, because: The requirements for requesting a bankrupt statement make it easy for the debtor to be declared bankrupt, even though the debtor is actually in a solvency state; The PKPU mechanism has not provided extensive opportunities for debtors to improve company performance; Efforts in bankruptcy are dominated by the authority of creditors.

- The factors that influence the implementation of the debtor's legal protection of bankruptcy by a separated creditor are: There are no funds for the costs of arranging and clearing bankrupt assets; Bankrupt debtors are not cooperative; Debtors sell / transfer assets before bankruptcy.

\subsection{Suggestion}

It is necessary to regulate policies relating to the legal protection of distributors for the rights of separatist creditors in bankruptcy matters. This is in accordance with the mandate of Article 18 of Law Number 8 of 1999 Related to the Standard Clause in Consumer Protection. So, the determination of bankruptcy billing not only looks at the interests of separatist creditors, but also on the debtor.

\section{References}

[1] Anwar, Jusuf. 2001. Peranan Hukum sebagai Sarana Perdagangan Surat Berharga Jangka Panjang dalam Rangka Pembangunan Nasional.Disertasi. Bandung : Program Pasca Sarjana Universitas Padjajaran

[2] Asshidiqie. Jimly. 1994. Gagasan Kedaulatan Rakyat dalam Konstitusi dan Pelaksanaannya di Indonesia. Jakarta : Ichtiar Baru Van Hoeve

[3] Aubert, Vilheml. 1986. Dillemmas of Law in Welfare State. European University Institute : Set.A Law

[4] Budiarjo, Miriam. 2001. Dasar-Dasar IImu Politik. Jakarta : Gramedia Pustaka Utama

[5] Cranston, Ross. 1985. Legal Foundations of the Welfare State. London : Weldenfeld and Nicolson

[6] Gamer,A. 1990. Black's Law Dictionary. Seventh Edition. Minn : West Group

[7] Asshidiqie, Jimmly. Strukktur Ketatanegaraan Indonesia Setelah Perubahan Keempat UUD Tahun 1945, makalah disampaikan pada Seminar Pembangunan Hukum Nasional VIII, Denpasar, 14-18 Juli 2003

[8] Direktorat Jenderal Perimbangan Keuangan Departemen Keuangan Kementerian Keuangan Republik Indonesia.2007. Panduan Penerbitan Obligasi Daerah.

[9] Kumoroto, Wahyudi. 2011. Pendapatan Asli Daerah dan Pembiayaan Pembangunan. Kajian disampaikan pada Forum Diskusi DPRD Kabupaten Kebumen. 
eISSN : 2581-2114, pISSN: 2406-9426

[10] Madya, Widyaiswara. Tanpa Tahun. Kenapa Obligasi Daerah Menarik untuk Diterbitkan?. Artikel pada Pusdiklat KNPK

[11] Narendra Nando.2015. Mengupas Kesulitan Penerbitan Obligasi Daerah. diakses di www. hukumonline.com/berita/mengupas-kesulitan-penerbitan-obligasi-daerah

[12] Okta, Dewi dan David Kaluge. Analisis Peluang Penerbitan Obligasi Daerah sebagai Alternatif Pembiayaan Daerah. Jurnal pada Journal of Indonesian Applied Economics Vol.5 No.2 Oktober 2011

[13] Purwoko. 2011. Analisis Peluang Penerbitan Obligasi Daerah Sebagai Alternatif Pembiayaan Infrastruktur Daerah. Artikel pada kajian fiskal Departemen Keuangan Kementerian Keuangan Republik Indonesia 